\title{
Acid Catalyzed Disproportionation of Anthrahydroquinone to Anthraquinone and Anthrone
}

\author{
Bernd WERMECKES and Fritz BECK*
}

Received June 10, 1994 ; August 5, 1994

\begin{abstract}
The reversible organic redox couple anthraquinone/anthrahydroquinone is of considerable interest for an application in metal free rechargeable batteries, mainly in acid electrolytes, e.g. in aqueous sulfuric acid. But the anthrahydroquinone undergoes an acid catalyzed disproportionation reaction to yield anthraquinone and anthrone. The dependency of this irreversible second order side reaction on the type of the acid, the acid concentration and the solvent was investigated by kinetic measurements in homogeneous solutions.
\end{abstract}

\section{INTRODUCTION}

Quinones are well known to form reversible organic redox couples. The kinetics of the benzoquinone/benzohydroquinone redox system was studied in detail four decades ago ${ }^{11}$. For a possible metal free secondary battery application chloroanil was proposed as the positive (redox potential, vs. $\mathrm{SHE}, \mathrm{U}_{\mathrm{H}, 0}=0.67 \mathrm{~V}$, electrochemical equivalent, $\left.\mathrm{m}_{\mathrm{e}}=0.22 \mathrm{Ah}^{-1}\right)$ and anthrahydroquinone as the negative $\left(\mathrm{U}_{\mathrm{H}, 0}=\right.$ $0.15 \mathrm{~V}, \mathrm{~m}_{\mathrm{e}}=0.26 \mathrm{Ah}^{-1}$ ) using sulphuric acid as electrolyte. This type of a "quinone battery"2), however, exhibited a voltage of only $0.5 \mathrm{~V}$. More recently, the negative anthraquinone system was combined with the very positive graphite intercalation compounds of the graphite salt type in acids of medium concentrations to yield threefold cell voltages of $\left.1.5 \mathrm{~V}^{3}, 4\right)$. In this connection, an irreversible side reaction, the acid catalyzed disproportionation of the anthrahydroquinone $\underline{1}$ to anthraquinone $\underline{2}$ and anthrone $\underline{3}$ according to equation (1) became interesting. Besides a qualitative observation ${ }^{5)}$ and an electrode kinetic study in 85 wt \%

Universität Duisburg, Gesamthochschule

Fachgebiet Elektrochemie

Lotharstraße 1, D-47057 Duisburg (Germany)

Key Words: Anthraquinone, Anthrahydroquinone, Anthrone, Disproportionation

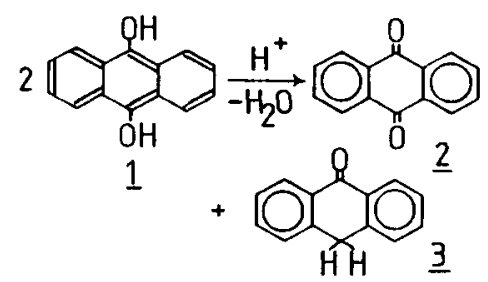

$\mathrm{H}_{2} \mathrm{SO}_{4}{ }^{6)}$, no kinetic data were available in acid electrolytes of medium concentrations. It is the aim of this paper to fill this gap.

\section{EXPERIMENTAL}

Galvanostatic cycling of an anthraquinone/carbon black single electrode was performed in a cylindric polyethylene cell with a $44 \mathrm{~cm}^{2}$ horizontal Acheson graphite electrode at the bottom of the cell. A mixture of $1.326 \mathrm{~g} \underline{2}$ with 30 wt \% carbon black c.b. (Corax L) was spread evenly on this current collector. A microporous separator was pressed onto this layer. The counter electrode was Pt. Cycling was performed at $\mathrm{j}=3 \mathrm{~mA} / \mathrm{cm}^{2}$ between the potential limits $+0.58 \ldots-0.31 \mathrm{~V}$ vs. SHE.

For the evaluation of the disproportionation kinetics two different systems were investigated. Because of the low water solubility of $\underline{1}$, $2 \cdot 10^{-5} \mathrm{M}$ (= mol dm${ }^{-3}$ ), the following organic solvents were applied: 80 vol\% $\mathrm{CH}_{3} \mathrm{CN}$, acetic 
acid, $\mathrm{HOAc}$, and acetic anhydride, $\mathrm{Ac}_{2} \mathrm{O}$, with 1,3 and $5 \mathrm{M} \mathrm{H}_{2} \mathrm{SO}_{4}$. For the pure aqueous systems with three different acids, $\mathrm{H}_{2} \mathrm{SO}_{4}(1 \mathrm{M}$, $3 \mathrm{M}$ and $5 \mathrm{M}$ ), $\mathrm{H}_{2} \mathrm{~F}_{2}$ (2 $\mathrm{M}$ and $20 \mathrm{M}$ ), and $\mathrm{HBF}_{4}$ (2 $\mathrm{M}$ and $4 \mathrm{M}$ ), the water soluble $\left(10^{-2} \mathrm{M}\right)$ anthrahydroquinone-2-sulphonic acid $\underline{4}$ was employed. The two anthrahydroquinones were prepared by reduction of the anthraquinones (each $0.1 \mathrm{~mol}$ ), introduced as a finely dispersed solid into $200 \mathrm{ml}$ of an aqueous solution, containing $0.1 \mathrm{~mol}$ sodiumdithionite and $0.4 \mathrm{~mol}$ $\mathrm{NaOH}^{7)}$. The sodium salt of $\mathrm{AQH}_{2} \quad 1$, $\mathrm{C}_{14} \mathrm{H}_{8} \mathrm{O}_{2} \mathrm{Na}_{2}$, was formed from $\mathrm{AQ} \underline{2}$. All procedures were performed under an argon atmosphere to rule out a parallel autoxidation. In the case of $\underline{4}$ an aqueous solution of the sodium salt of anthraquinone-2-sulphonic acid $\mathrm{C}_{14} \mathrm{H}_{7} \mathrm{SO}_{5} \mathrm{Na}$ was used instead of the free acid. It was reduced to the anthrahydroquinone sodium salt $\mathrm{C}_{14} \mathrm{H}_{7} \mathrm{SO}_{5} \mathrm{Na}_{3}$. Rapid conversion to 4 was accomplished by adding to the large excess of acid media.

For the kinetic studies of reaction (1) in acid, the standard starting concentration of 1 and 4 was $6 \mathrm{mM}$. The overall volume at the beginning was $200 \mathrm{ml}$. In the course of the kinetic measurements the concentration of nonconverted $\underline{1}$ and $\underline{4}$, respectively, was determined by redox titration with $0.0125 \mathrm{M} \mathrm{FeCl}_{3}$ solution. A $10 \mathrm{ml}$ probe of the reaction solution was diluted with $40 \mathrm{ml} 1: 1 \mathrm{vol} / \mathrm{vol}$ acetone/water mixture in the case of 1 and $40 \mathrm{ml}$ water in the case of $\underline{4}$. The titration solution had to be changed to $0.1 \mathrm{M} \mathrm{Ce}\left(\mathrm{SO}_{4}\right)_{2}$ solution in the case of $\mathrm{H}_{2} \mathrm{~F}_{2}$.

\section{RESULTS}

Figure 1 shows the active material utilization $\mu$ in the course of the galvanostatic cycling experiments with $0.5,2,6$ and $8 \mathrm{M} \mathrm{HBF}_{4} . \mu$ refers to the theoretical value for $2 \mathrm{~F} / \mathrm{mol} \mathrm{AQ}$, which is $860 \mathrm{C}$. At the beginning, $\mu$ is in the range of $50-60 \%$. But it decreases significantly

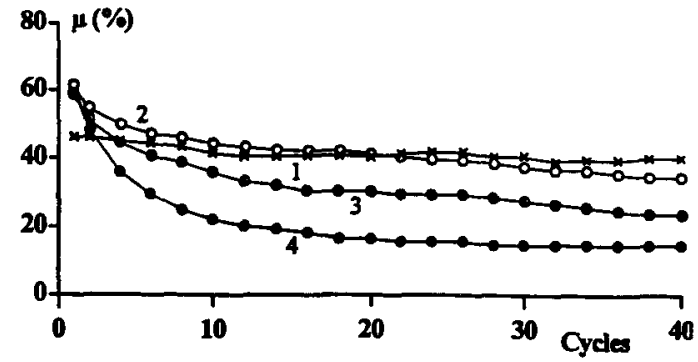

Fig.] $\mu$ for galvanostatic cycling of AQ (30\% c.b.) in $\mathrm{HBF}_{4} .1: 0.5 \mathrm{M} ; 2: 2 \mathrm{M} ; 3: 6 \mathrm{M} ; 4: 8 \mathrm{M}$

in the course of the initial 42 cycles at the higher acid concentrations. $\mu=50 \%$ corresponds to a discharge time of 3257 seconds.

The kinetic measurements in acid solutions of the anthrahydroquinones $\underline{1}$ and $\underline{4}$ led to the following results: The reaction order for 1 was determined after the half-life method to be $\nu=$ 1.8 in the average with respect to the substrate 1. Consequently, the kinetic results were plotted in Figures 2 and 3 (see next page) according to a second order law. Clearly, straight lines are found in all cases. Figure 2 displays the kinetic curves in 1-5 $\mathrm{M} \mathrm{H}_{2} \mathrm{SO}_{4}$ in 80 vol\% $\mathrm{CH}_{3} \mathrm{CN}$. 1 is relatively stable in $2 \mathrm{M} \mathrm{H}_{2} \mathrm{SO}_{4}$, but it decomposes rapidly in $3 \mathrm{M}$ and even more in $5 \mathrm{M}$ $\mathrm{H}_{2} \mathrm{SO}_{4}\left(80 \mathrm{vol} \% \mathrm{CH}_{3} \mathrm{CN}\right)$. In $1 \mathrm{M} \mathrm{H}_{2} \mathrm{SO}_{4}$ in this solvent, virtual stability is achieved. Second order rate constants are derived from this, and they are compiled in Table 1. Very high rates were found in acetic acid (No 14, 3 $\left.\mathrm{M}_{2} \mathrm{SO}_{4}\right)$ and even more in acetic anhydride (No 15, $1 \mathrm{M} \mathrm{H}_{2} \mathrm{SO}_{4}$ ).

The solvent effect as well as the substituent effect was studied in the course of further measurements, which are compiled in Fig. 3. It can be seen, that the decomposition is appreciable slower for $\underline{4}$, and it varies only slightly with the $\mathrm{H}_{2} \mathrm{SO}_{4}$-concentration. A comparison of curves 3 and 5 for 4 at the same $\mathrm{H}_{2} \mathrm{SO}_{4}$-concentration ( $3 \mathbf{M})$ shows, that the rates are much faster in $80 \mathrm{vol} \% \mathrm{CH}_{3} \mathrm{CN}$. Table 1 includes also a previous result in $85 \% \mathrm{H}_{2} \mathrm{SO}_{4}$ (entry No $13^{6)}$ ) and with other acids. 


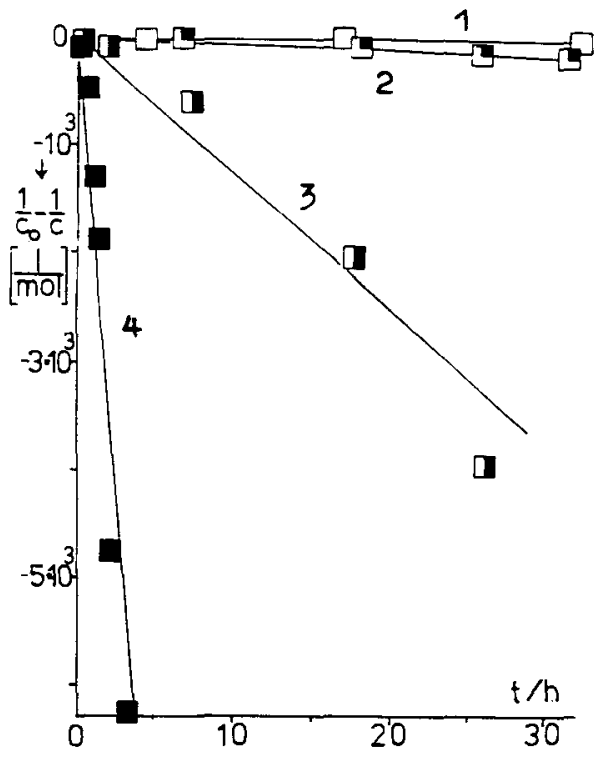

Fig. 2 Kinetic curves of the disproportionation of $\underline{1}(6 \mathrm{mM})$ in 80 vol\% $\mathrm{CH}_{3} \mathrm{CN}$ with various $\mathrm{H}_{2} \mathrm{SO}_{4}$ concentrations: $1: 1 \mathrm{M} ; 2: 2 \mathrm{M} ; 3: 3 \mathrm{M} ; 4: 5 \mathrm{M}$

\section{DISCUSSION}

A dramatic effect of the acid concentrations $\mathrm{c}_{\mathrm{A}}$ on $\mathrm{k}_{2}$ is shown in Table 1 , entries $1-4$, in the case of the unsubstituted $\mathrm{AQH}_{2} \underline{1}, \mathrm{k}_{2}$ rises exponentially with $\mathrm{c}_{\mathrm{A}}$. However this holds only for $80 \mathrm{vol} \% \mathrm{CH}_{3} \mathrm{CN}$, where this is attributed to the presence of the very strong acid $\left(\mathrm{CH}_{3} \mathrm{CNH}\right)^{+}$in the equilibrium. Acetic acid (entry 14) exhibits also a pronounced amplification of the acidity of the dissolved acids as usual. The strong effect of acetanhydride (entry 15) may be rationalyzed through the presence of an acetyl cation $\mathrm{CH}_{3} \mathrm{CO}^{+}$.

There is also a substituent effect operative, as demonstrated with the anthrahydroquinone2 -sulphonic acid 4 . The rate constants $k_{2}$ are lower by a factor 10 with respect to 1 in 80 vol\% $\mathrm{CH}_{3} \mathrm{CN}$, cf. entry 5 . This may be a consequence of the electron withdrawing substituent, which retards the initial protonation step in the mechanism ${ }^{6)}$. The standard redox potential was $0.19 \mathrm{~V}$ vs. SHE, which is more positive than that of $\mathrm{AQ}(0.15 \mathrm{~V}$ vs. SHE).
Entries 6-8 in Table 1 demonstrate, that in water, the acidity effect is much lower in 1-5 M $\mathrm{H}_{2} \mathrm{SO}_{4}$ and in the other aqueous acids, cf. entries No 6-12. This is interesting for the application in batteries with aqueous acids. Even in $15.4 \mathrm{M} \mathrm{H}_{2} \mathrm{SO}_{4}$, this effect is maintained (entry No 13). $k_{2}$ is relatively low, it would be 13 orders of magnitude higher, if the exponential rise of $\mathrm{k}_{2}$ in $1-5 \mathrm{M} \mathrm{H}_{2} \mathrm{SO}_{4}$ in 80 vol\% $\mathrm{CH}_{3} \mathrm{CN}$ would be continued up to $15.4 \mathrm{M}$ $\mathrm{H}_{2} \mathrm{SO}_{4}$.

In batteries, electrodes of the second kind, represented by a mixture of $\mathrm{AQ}$ and carbon black, will be employed, cf. ${ }^{8}$. As the solubility of $\mathrm{AQ}$ and $\mathrm{AQH}_{2}$ is very low, $\mathrm{c}_{\mathrm{s}}=2 \cdot 10^{-5} \mathrm{M}$ in the diluted acids according to our analytical determination, the rate of the second order reaction (1) is appreciably lower according to $-\mathrm{dc} / \mathrm{dt}=\mathrm{k}_{2} \mathrm{c}^{2}$. As $\mathrm{c}_{0}=6 \mathrm{mM}$, but $\mathrm{c}_{\mathrm{s}} \simeq 0.01$ $\mathrm{mM}$, it is a factor $(1 / 600)^{2}=1 / 360000$ with respect to the initial rate. Unfortunately, we do not know $k_{2}$ for acids of medium concentra-

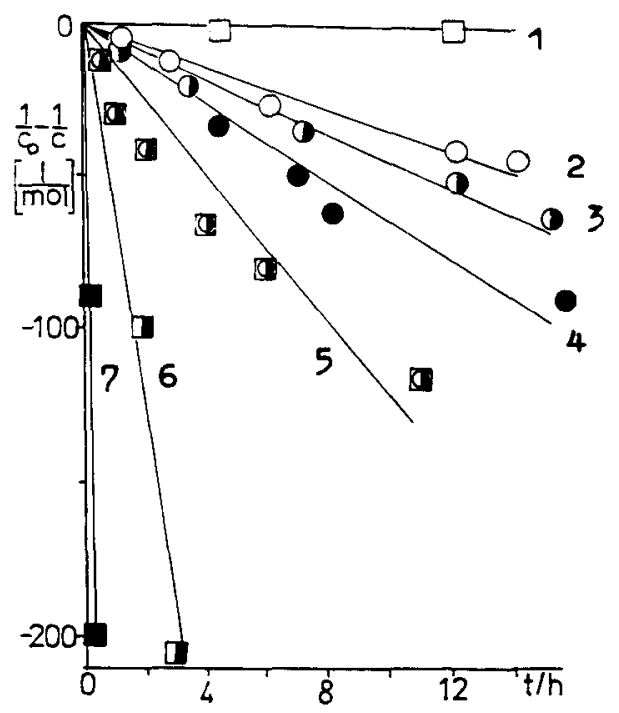

Fig. 3 Kinetic curves of the disproportionation of 1 and $4(6 \mathrm{mM})$ for various $\mathrm{H}_{2} \mathrm{SO}_{4}$ concentrations $(\overline{\mathrm{M}}) .80$ vol\% $\mathrm{CH}_{3} \mathrm{CN}: 1: 1$ (1 M), 5: $\underline{4}$ (3 M), 6: 1 (3 M), 7: 1 (5 M); water: 2: $\underline{4}(1$ M), 3: 4 (3 M), 4: 4 (5 M) 
Table 1 Rate constants for the 2nd order reaction (1) measured at $20^{\circ} \mathrm{C}$

\begin{tabular}{|c|c|c|c|c|c|}
\hline No & Educt & Solvent & Acid & $c_{A} / M$ & $\mathbf{k}_{2} / \mathrm{dm}^{3} \mathrm{~mol}^{-1} \mathrm{~h}^{-1}$ \\
\hline $\begin{array}{l}1 \\
2 \\
3 \\
4\end{array}$ & $\begin{array}{l}\frac{1}{1} \\
\frac{1}{1} \\
\frac{1}{1}\end{array}$ & $\begin{array}{l}80 \text { vol\% } \mathrm{CH}_{3} \mathrm{CN} \\
80 \text { vol\% } \mathrm{CH}_{3} \mathrm{CN} \\
80 \text { vol\% } \mathrm{CH}_{3} \mathrm{CN} \\
80 \text { vol\% } \mathrm{CH}_{3} \mathrm{CN}\end{array}$ & $\begin{array}{l}\mathrm{H}_{2} \mathrm{SO}_{4} \\
\mathrm{H}_{2} \mathrm{SO}_{4} \\
\mathrm{H}_{2} \mathrm{SO}_{4} \\
\mathrm{H}_{2} \mathrm{SO}_{4}\end{array}$ & $\begin{array}{l}1 \\
2 \\
3 \\
5\end{array}$ & $\begin{array}{r}0.2 \\
4.4 \\
126 \\
1575\end{array}$ \\
\hline 5 & $\underline{4}$ & $80 \mathrm{vol} \% \mathrm{CH}_{3} \mathrm{CN}$ & $\mathrm{H}_{2} \mathrm{SO}_{4}$ & 3 & 12 \\
\hline $\begin{array}{l}6 \\
7 \\
8\end{array}$ & $\begin{array}{l}\frac{4}{4} \\
\underline{4}\end{array}$ & $\begin{array}{l}\mathrm{H}_{2} \mathrm{O} \\
\mathrm{H}_{2} \mathrm{O} \\
\mathrm{H}_{2} \mathrm{O}\end{array}$ & $\begin{array}{l}\mathrm{H}_{2} \mathrm{SO}_{4} \\
\mathrm{H}_{2} \mathrm{SO}_{4} \\
\mathrm{H}_{2} \mathrm{SO}_{4}\end{array}$ & $\begin{array}{l}1 \\
3 \\
5\end{array}$ & $\begin{array}{l}3.0 \\
4.0 \\
6.5\end{array}$ \\
\hline $\begin{array}{r}9 \\
10 \\
11 \\
12\end{array}$ & $\begin{array}{l}\frac{4}{4} \\
\frac{4}{4} \\
\frac{4}{4}\end{array}$ & $\begin{array}{l}\mathrm{H}_{2} \mathrm{O} \\
\mathrm{H}_{2} \mathrm{O} \\
\mathrm{H}_{2} \mathrm{O} \\
\mathrm{H}_{2} \mathrm{O}\end{array}$ & $\begin{array}{c}\mathrm{HBF}_{4} \\
\mathrm{HBF}_{4} \\
\mathrm{H}_{2} \mathrm{~F}_{2} \\
\mathrm{H}_{2} \mathrm{~F}_{2}\end{array}$ & $\begin{array}{c}2 \\
4 \\
2 \\
20\end{array}$ & $\begin{array}{l}2.0 \\
2.7 \\
7.0 \\
9.0\end{array}$ \\
\hline 13 & $\underline{1}$ & $\mathrm{H}_{2} \mathrm{O}$ & $\mathrm{H}_{2} \mathrm{SO}_{4}$ & 15 & $\left.3.0 \cdot 10^{4} 8\right)$ \\
\hline $\begin{array}{l}14 \\
15\end{array}$ & $\frac{1}{1}$ & $\begin{array}{l}\mathrm{HOAc} \\
\mathrm{Ac}_{2} \mathrm{O}\end{array}$ & $\begin{array}{l}\mathrm{H}_{2} \mathrm{SO}_{4} \\
\mathrm{H}_{2} \mathrm{SO}_{4}\end{array}$ & $\begin{array}{l}3 \\
1\end{array}$ & $\begin{array}{l}1035 \\
\quad 5.0 \cdot 10^{8}\end{array}$ \\
\hline
\end{tabular}

tions. But for $85 \% \mathrm{H}_{2} \mathrm{SO}_{4}, \mathrm{k}_{2}=3 \cdot 10^{4}$ was established formerly by three independent electrochemical methods ${ }^{6}$ ). If we assume a small acid concentration effect in aqueous acids, cf. entries 6-13 in Table 1 , the relevant values for the cycling experiment (Figure 1) should be not very much below this value. The $\mu$ drops linearly in the later stages of the cycling experiment, with a rate of about $1 \%$ per cycle as it is to be expected from $c_{s}=$ constant. The "residence time" of the $\mathrm{AQH}_{2}$ can be estimated to be about 1 hour per cycle. According to Vetter's theory ${ }^{9}$, an electrode of the second kind in batteries, e.g. $\mathrm{Pb} / \mathrm{PbSO}_{4}$, works through the transport of free, dissolved species, e.g. $\mathrm{Pb}^{++}$, within the pores of the electrode. The transport length is rather constricted. The following expression can be easily derived:

$$
\mathbf{k}_{2}=\Delta \mathrm{m} /\left(\Delta \mathrm{t} \mathrm{c}_{\mathrm{s}}^{2} \mathrm{MV}\right)
$$

where $\mathrm{V}=$ electrolyte volume and $\mathrm{M}=$ mole mass of $\mathrm{AQH}_{2}$. With $\Delta \mathrm{m} / \Delta \mathrm{t}=0.013 \mathrm{~g} / \mathrm{h}, \mathrm{c}_{\mathrm{s}}=$ $2 \cdot 10^{-5} \mathrm{M}$, see above, and $\mathrm{V}=0.21, \mathrm{k}_{2} \simeq 10^{6} \mathrm{l}$ $\mathrm{mol}^{-1} \mathrm{~h}^{-1}$ is obtained, which is even somewhat higher as the evaluation given above. In conclusion, substituted anthraquinones must be developed with a lower $k_{2}{ }^{4}$ ).

We are indebted to the Ministery of Science and Research in Düsseldorf for financial support of this work.

\section{REFERENCES}

1) K. J. Vetter, Z. Elektrochem., 56, 797 (1952).

2) H. Alt, H. Binder, A. Köhling and G. Sandstede, J. Electrochem. Soc., 118, 1950 (1971).

3) F. Beck, T. Boinowitz, H. Krohn, U. Tormin and E. Ther, Mol. Cryst., Liqu. Cryst., 245, 177 (1994).

4) German Pat. Appl. 4333040 (30.9.1993), I. Barsukov.

5) M. A. Matthews, J. Chem Soc. (London), 1926, 237.

6) F. Beck and G. Heydecke, Ber. Bunsenges. Phys. Chem., 91, 37 (1987).

7) D. R. Dimmel and D. Shepard, J. Org. Chem., 47, 26 (1982).

8) V. V. Matveev, N. V. Korneev, V. Z. Barsukov and N. B. Ilyuk, J. Power Sourc., (1994), in press.

9) K. J. Vetter, Chem. - Ing. - Tech. 45, 213 (1973). 